\title{
Elementary School Students' Character Conditions During Online Learning
}

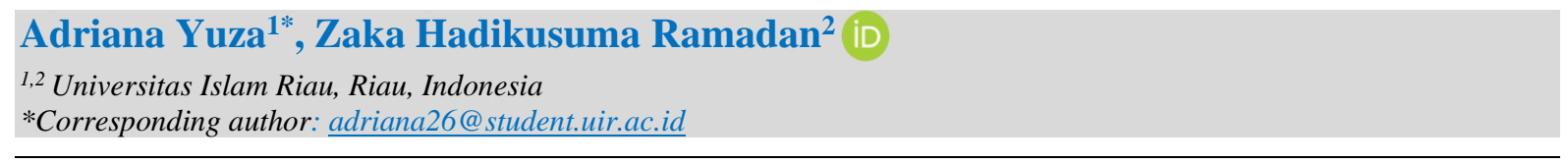

\section{Abstract}

Online learning today was said to be unsuccessful and far from expected. It had a less good impact on the formation of characters where children depend heavily on parents and less interaction with others. This was one reason for research aimed at analyzing the implementation of character value in online learning. This type of research is qualitatively discrete. Data was collected from the principal, two teachers who have been certified who have taught for 15 years after the local content teacher. Data collection methods include interviews and observations. The data analysis used was triangulation. The research results stated that implementing the main character values, namely religion, nationalism, media, teamwork, and integrity, is not carried out in the implementation and evaluation stages because learning is done online. So, in online learning, the central values of religion, nationalism, media, teamwork, and integrity are not done, to overcome this can be done by conducting supervision programs.

Keywords: Children's Character; Online Learning

\begin{tabular}{lll}
\hline History: & & Publisher: Undiksha Press \\
Received & : April 03, 2021 & Licensed: This work is licensed under \\
Revised & : April 05, 2021 & a Creative Commons Attribution 3.0 License \\
Accepted & : June 10, 2021 &
\end{tabular}

\section{INTRODUCTION}

Pandemic covid-19 is one of the severe problems that cause many changes in all areas of human hypocrisy (Wong et al., 2020). One area that is changing is education. Many activities that must be postponed and even stopped such activities such as comparative studies, seminars, and activities that can cause commutations and learning processes conducted that initially is face-to-face learning turned into online learning (Mishra et al., 2020; Oyedotun, 2020; Patricia, 2020; Sahu, 2020). Online learning is learning done with the help of the internet both in sync and asynchronously that provides opportunities for interaction of learners with learning resources both educators/environment and peers (Dong et al., 2020a). Online learning provides students with the opportunity to share their opinions and learn more independently indefinitely, and space is more flexible (Hwang et al., 2020; Kkese, 2020; Lage-Cala et al., 2020). Online learning is in dire need of educators' and learners' ability because the ability to use technology will be beneficial to create a more conducive learning atmosphere so that a good social interaction is formed (Andel et al., 2020). So, online learning will produce a good quality of education if all components or learning facilities support it well.

However, after online learning is applied, many students cannot use technology difficulties in online learning. Parents are not ready to accompany their studies because they are busy working and do not understand the materials provided (Dong et al., 2020b). Many children do not do online learning, do activities other than learning such as playing games, social media, watching more youtube, and other activities that indicate an addiction to "gawe"(Liu et al., 2020; Rahmawati \&Latifah, 2020; Samaha \&Hawi, 2016). Lack of interaction in online learning makes students can not spell the same well (Cahyono et al., 2018). And most concerningly, during online learning, students depend a lot on parents in 
spelling out assignments and knowledge, students are less sympathetic in education. Even in online learning, many character values are lost, such as students using profanity (Kurniawan et al., 2019), unwillingness to interact with the environment, and much more. There are many anti-social adolescent behaviors such as drug use, sexual harassment, and school burning (Amollo \&Lilian, 2017).

This condition is in line with the observations made where there is still a low character value in students, such as religious values and integrity values where there are one of the students of grade IIIB who their parents often call to school because they often use profanity when interacting with their friends even with their teachers, often fighting during the learning process. Outside the learning process, often disturbing friends, according to the teacher of class III B, these students come from busy families so that parents' attention to their children is more minor. The close home distance from the market, then the students denounce each other using profanity that ultimately causes fights in the classroom and outside the classroom, on the value of self-reliance that is in the learning of learners, there are still many who cheat the answer from his next friend even though he has answered the question of the question. Still, the lack of confidence in the solution, on the value of nationalism at the flag ceremony, has many less orderly students such as talking to his friend. On the importance of cooperation that is difficult for learners to do good cooperation as evidenced when conducting group discussions. There are always fights because the members of the group given or chosen by the teacher are not following what the learner wants. This condition is certainly not good if it is cast as it will form a human being who is not characterful that will later harm the Nation and State.

Many solutions can be offered to solve this problem, one of which is implementing character education. Character education is an effort to educate, cultivate and state and form a community so that human beings have noble behavior and morals (Abdullah et al., 2015; Adibatin, 2016; Barry et al., 2013; Birhan et al., 2021). Character education has improved student behavior, reducing bully, conflict, and violence(Ansori, 2020b). Character education impacts attitude change through continuous habituation (Cheung \&Lee, 2010; Suheli, 2018). Education can improve students' morale (Heidari et al., 2016), good morals will make learners successful. Given that a person succeeds not only because of how oppressed a person is but how strong a person's rubber is. Successful students need some character: honesty, love saying, loyalty, respect, trust, responsibility, good integrity, ethics, and nationalism (Mei-Ju et al., 2014). The explanation gives an idea of how vital character education should be given in the education of children. Character education is widely done and combined with other learning approaches so that it is done holistically. But nowadays, character education is challenging to deal with holistically, considering the current learning is done online. This is the research that aims to assess the implementation of student character values in online education. The character score is analyzed from the importance of religion, nationalism, independence, cooperation, and integrity. Knowing the situation of the application of character values in schools gives an idea of how the current condition of students speak with their character to provide support if there are problems with the implementation of character education.

\section{MATERIALS AND METHODS}

The type of research used in this study is qualitative descriptive research. The research procedure consists of the determination of problems; problems are based on the results of initial observations related to character score; determination of title; determine the direction of study, the focus of the research to be researched is how to plan, implement, and evaluate the implementation of rubber value; the research stage, the research that will be 
conducted on the focus of research by using qualitative research; the set of data collection, collecting data using interview data collection techniques, observation and documentation; and analysis data, after all the data collected then conducted data analysis, researchers use Miles and Huberman data analysis namely data reduction, data presentation, and conclusion withdrawal. The data was collected from the principal, two certified teachers, namely the teacher of grades 5 and 6 , and one teacher of local content BMR.

The research data was conducted with interviews, observations, and documentation studies. The purpose of the interview is to obtain data and know in-depth about the planning, implementing, and evaluating five central character values (religion, nationalism, independence, cooperation, and integrity). The interview will be conducted or started by asking the principal to interview him, the teacher, and meet the source to be interviewed. The observation here, observation participated (observation participants) with passive involvement where the researchers were not directly involved in the activities carried out by the objects studied, but the researchers only observed. Researchers will observe how to plan, implement and evaluate the implementation of 5 central character values (religious, nationalism, independence, mutual assistance, and integrity). Documentation using documents as evidence in the form of photos/drawings, audio recordings of interviews and documents such as vision and mission, objectives, learning programs that are; data on the number of students in the classroom and the number of homeroom guardians, study time, schedule of excellent programs and habituation of schools, extracurricular programs, curriculum used by schools and others that can support the truth of the interview results.

This study uses analysis techniques from Miles and Huberman (Sugiyono, 2017), consisting of Data Collection; Data Reduction; Data Display, and Conclusion drawing/verification. The test on qualitative research includes trust, reliability, dependency, and certainty. Credibility test of qualitative research data was conducted by extension of observation, increased perseverance in research, triangulation, discussion with colleagues, negative case analysis, and member check. This transferability relates to the question of the extent to which the study results can be applied or used in other social contexts and situations. A dependability test is conducted by auditing the entire research process. Testing the affirm ability means trying the results of research associated with the procedure performed. If the study results are a function of the process carried out, then the research has met the standards of affirmability.

\section{RESULTS AND DISCUSSION}

Research aimed at analyzing the implementation of character values from aspects of planning, implementation, and evaluation. Interviews, observations, and documentation from principals and teachers. From these results obtained several things. First, implementation in learning activities / in the classroom in thematic learning. Based on the interview results obtained, although the Syllabus and RPP have not listed five central character values, teachers have applied the character value in real terms. Implementation of 5 central character values in thematic learning are: 1) Religious values: recitation, prayer, greetings. 2) The value of nationality: reading Pancasila and singing regional and national songs 3) The value of self-reliance: answering the evaluation questions, testing independently without cheating, and asking others. 4) Value of teamwork: cooperate in discussion activities, pickets, and teamwork. And 5) Integrity value: students were required to be honest in working on problems. At the same time, the observation results were not in line with the results of interviews where during the learning process did not appear to be character scores that were inserted into the learning. In contrast, the results of the documentation in thematic RPP 5 rubber value were listed. Second, implementation in learning activities / in the classroom in 
local content learning. Based on the results of an interview with the principal on February 08, 2021, that in the local content of Riau Malay Culture (BMR) how to implement five central character values course; teachers should be an example for their students, and in learning activities for more details students can ask directly to the teacher. Based on the interview results, teachers implementing five central character values in the learning of Riau Malay Culture (BMR) must provide good examples and role models for their students. In the implementation learning activities, namely: The interviews of principals and teachers could be obtained that implementing five central character values in Riau Malay Culture (BMR) learning (BMR) must provide a good example and role model for students. The learning activities of implementation are: 1) Religious values: saying greetings and praying before learning; 2) The value of nationality: learn more about Riau Malay culture; 3) The value of self-reliance: working on the problem independently; 4) Mutual value: cooperate in aligning group tasks, and 5) Integrity value: teach honest, polite and polite attitudes to parents, friends, and others. While the observations during learning, the implementation of 5 central character values in BMR local content learning does not exist, teachers only ask students to read printed books and give assignments. Learning is done online through the WhatsApp group. The study of BMR local content teacher documents using online RPP and teachers had not listed all of the five main character values into RPP.

Third, implementation in extracurricular activities. Based on the interview results, observations and documentation obtained those extracurricular activities cannot be done because the learning is still online. So the implementation of character values could not be applied. Extracurricular activities conducted were Silat, Pramuka, Art, and Drum band. Students would train and develop character cooperation, nationalism, cooperation integrity, and other character values if this was done. Fourth, implementation in evaluation activities. Based on the results of the interview that based on the PPK assessment guidelines, the assessment of PPK success is conducted internally involving stakeholders (principals, teachers, parents, and school committees) and externally can be done by parties from outside the school who have a common interest to succeed the implementation of the PPK Movement in schools, such as assessment teams from the Ministry of Education and Culture, the Education Office, and supervisors. Assessment/evaluation of learning in the classroom can be done by observing the activities of students inside based on the Syllabus and RPP that the teacher has designed. The results can then be seen in the student report card. Currently, this process cannot be done because the learning was conducted online.

The explanation provided an image of the implementation of character education during online learning. From these results, it can be said that character values were not given in online learning. This was due to the task-based learning method. The teacher assigns the task, and then the student will reassess the task. This learning was certainly not good for the learning process and character-building of students. Every character that will be developed must be realized in the content of each subject. Its form can be through tasks and homework, study materials, simulations, and also manifested in other academic regulations in schools. This way, students will be trained in a patterned manner, making learners accustomed to doing good to others (Nasution, 2017; Sutiyono, 2013). In addition, the formation of children's characters was not only habituated but must also begin as early as possible (Cahyaningrum et al., 2017; Suryaman \&Karyono, 2018). So elementary school children must be given character education. Character education is an effort to educate, cultivate and state and form a community so that human beings have noble behavior and morals (Abdullah et al., 2015; Adibatin, 2016; Barry et al., 2013; Birhan et al., 2021). Character education has improved student behavior, reducing bullying, conflict, and violence(Ansori, 2020b). Character education impacts attitude change through continuous habituation(Cheung \&Lee, 
2010; Suheli, 2018). Education can improve students' morale (Heidari et al., 2016; Suheli, 2018), good morals will make students successful.

However, the current condition of character values only exists in the lesson plan and was not applied, which impacted the decline of the child's character; this will be affected by the decay of the nation's character. The loss of the values of the character of this nation is not only influenced by the development of science and technology today. Moreover, it is influenced by the environment around the younger generation (Sudarmiani, 2013). It was evidenced today by children's violence, murders, and events concerning that the nature condition was now related. Many anti-social adolescent behaviors such as drug use, sexual harassment, and school burning (Amollo \&Lilian, 2017; Ansori, 2020a). This condition is inseparable from the learning process that was carried out. So solving the problem of learning that did not apply these character values can be done by doing supervision. Supervision, a principal can assist all school staff in general and teachers in particular by providing guidance that refers to improving the social competence of teachers (Huda, 2018; Mena et al., 2016). Supervise basically to provide services to teachers in improving the quality of learning in the classroom, to correct the shortcomings and weaknesses in teachers while teaching (Muhammad, 2019; Suradi, 2018) by conducting a head supervision program as if it can guide and find a way out of not carrying out education in the process of daily learning.

So, the implementation of well-done nature values will improve and develop the character of the child. This statement is in conjunction with the research results that states that there is an increase in children's character after implementing children's songs in the learning process (Rawin \&Brantasari, 2018; Wahyuningsih, 2017). Applying the PAIKEM learning model by playing agate stone can improve the character of students (Adibatin, 2016). Implementation of character education in the mind of outdoor social attitudes and behaviors in the learning process and become habitable to improve the attitudes and behaviors of social children (Utomo \&Muntholib, 2018). The implementation of character education integration in Arabic language learning is carried out through learning activities, advice, and teacher thoroughness in teaching Arabic. The integration of character education at the learning implementation stage was carried out in the philosophical, material, and strategic spheres (Amin et al., 2018). The explanation described that character education was still done well because the learning process is still face-to-face. In contrast to the results of this study that the implementation of character values is only done at the design stage.

\section{CONCLUSION}

In online learning implementation, the central character values of religion, nationalism, individualism, teamwork, and integrity are not implemented in the implementation and evaluation stages. To implement this, it was necessary to carry out the implementation of the head supervision to find the best solution to implement character education.

\section{REFERENCES}

Abdullah, B., Radiansyah, R., \& Akbar, A. (2015). Pendidikan Karakter Di Madrasah Aliyah $\begin{array}{lllll}\text { Negeri } & \text { (Man) } & 2 & \text { Banjarmasin. } & \text { Inferensi, }\end{array}$ https://doi.org/10.18326/infs13.v9i2.537-560.

Adibatin, A. (2016). Pendidikan Karakter Bangsa Berbasis Strategi Pembelajaran PAKEM Melalui Permainan Cincin di Jempol Tangan (Karya Inovasi Pembelajaran Sekolah Dasar). Scholaria: Jurnal Pendidikan Dan Kebudayaan, 6(1), 1. https://doi.org/10.24246/j.scholaria.2016.v6.i1.p1-18. 
Amin, M., Syahnaidi, Q., \& Baroroh, R. U. (2018). Integrasi Pendidikan Karakter dalam Pembelajaran Bahasa Arab di Sekolah Muhammadiyah. Journal of Arabic Studies, 3(2), 181-195. http://dx.doi.org/10.24865/ajas.v3i2.97.

Amollo, O. P., \& Lilian, G. K. (2017). Teacher Position in Spurring Value-Based Education in Early Learning in Nairobi County, Kenya: Addressing Support of Values in School Environment. Journal of Education and Learning, 6(3), 194. https://doi.org/10.5539/jel.v6n3p194.

Andel, S. A., de Vreede, T., Spector, P. E., Padmanabhan, B., Singh, V. K., \& Vreede, G. J. de. (2020). Do social features help in video-centric online learning platforms? A social presence perspective. Computers in Human Behavior, 113(April), 106505. https://doi.org/10.1016/j.chb.2020.106505.

Ansori, Y. Z. (2020a). Pembinaan Karakter Siswa Melalui Pembelajaran Terpadu Di Sekolah Dasar. Jurnal Educatio FKIP UNMA, 6(1), 177-186. https://ejournal.unma.ac.id/index.php/educatio/article/download/308/202/.

Ansori, Y. Z. (2020b). Penguatan karakter disiplin siswa melalui peranan guru di sekolah dasar. Jurnal Elementaria Edukasia, 3(1), 126-135.

Barry, A. L., Rice, S., \& McDuffie-Dipman, M. (2013). Books with potential for character education and a literacy-rich social studies classroom: A research study. Journal of Social Studies Research, 37(1), 47-61. https://doi.org/10.1016/j.jssr.2012.12.002.

Birhan, W., Shiferaw, G., Amsalu, A., Tamiru, M., \& Tiruye, H. (2021). Exploring the context of teaching character education to children in preprimary and primary schools. Social Sciences \& Humanities Open, 4(1), 100171. https://doi.org/10.1016/j.ssaho.2021.100171.

Cahyaningrum, E. S., Sudaryanti, S., \& Purwanto, N. A. (2017). Pengembangan Nilai-Nilai Karakter Anak Usia Dini Melalui Pembiasaan Dan Keteladanan. Jurnal Pendidikan Anak, 6(2), 203-213. https://doi.org/10.21831/jpa.v6i2.17707.

Cahyono, B., Tsani, D. F., \& Rahma, A. (2018). Pengembangan Buku Saku Matematika Berbasis Karakter pada Materi Trigonometri. Jurnal Phenomenon, 08(2), 185-199. https://doi.org/http://dx.doi.org/10.21580/phen.2018.8.2.2929.

Cheung, C. kiu, \& Lee, T. yan. (2010). Improving social competence through character education. Evaluation and Program Planning, 33(3), 255-263. https://doi.org/10.1016/j.evalprogplan.2009.08.006.

Dong, C., Cao, S., \& Li, H. (2020a). Young children's online learning during COVID-19 pandemic: Chinese parents' beliefs and attitudes. Children and Youth Services Review, 118(August), 105440. https://doi.org/10.1016/j.childyouth.2020.105440.

Dong, C., Cao, S., \& Li, H. (2020b). Young children's online learning during COVID-19 pandemic: Chinese parents' beliefs and attitudes. Children and Youth Services Review, 118(June), 105440. https://doi.org/10.1016/j.childyouth.2020.105440.

Heidari, M. H., Nowrozi, R. A., \& Ahmadpoor, P. (2016). Recognition and Applying Character Education Approaches in Schools. Review of European Studies, 8(3), 125. https://doi.org/10.5539/res.v8n3p125.

Huda, M. N. (2018). Peran Kompetensi Sosial Guru dalam pendidikan. Ta'dibi : Jurnal Prodi Manajemen Pendidikan Islam, 2(September 2017), 227-249. https://ejurnal.stail.ac.id/index.php/tadibi/article/download/Peran Kompetensi Sosial Guru dalam pendidikan/3.

Hwang, G. J., Wang, S. Y., \& Lai, C. L. (2020). Effects of a social regulation-based online learning framework on students' learning achievements and behaviors in mathematics. Computers and Education, 160, 104031. https://doi.org/10.1016/j.compedu.2020.104031.

Kkese, E. (2020). McGurk effect and audiovisual speech perception in students with learning 
disabilities exposed to online teaching during the COVID-19 pandemic. Medical Hypotheses, 144(July), 110233. https://doi.org/10.1016/j.mehy.2020.110233.

Kurniawan, A. R., Chan, F., Pratama, A. yohan, Yanti, M. T., Fitriani, E., Mardani, S., \& Khosiah. (2019). Analisis Degradasi Moral Sopan Santun Siswa di Sekolah Dasar. Jurnal Pendidikan Ips, 9(2), 104-122. https://doi.org/10.37630/jpi.v9i2.189.

Lage-Cala, S., Folgueras-Díaza, M. B., Alonso-Hidalgoa, M., García-Menéndezb, D., \& Fernández-Garcíab, F. J. (2020). Investigation of the effectiveness of online learning tools for energy performance certificates preparation. Energy Reports, 6, 609-614. https://doi.org/10.1016/j.egyr.2019.09.034.

Liu, Q., Huang, J., \& Zhou, Z. (2020). Self-expansion via smartphone and smartphone addiction tendency among adolescents: A moderated mediation model. Children and Youth Services Review, 119(June), https://doi.org/10.1016/j.childyouth.2020.105590.

Mei-Ju, C., Chen-Hsin, Y., \& Pin-Chen, H. (2014). The Beauty of Character Education on Preschool Children's Parent-child Relationship. Procedia - Social and Behavioral Sciences, 143, 527-533. https://doi.org/10.1016/j.sbspro.2014.07.431.

Mena, Y., Supriyanto, A., \& Burhhanudin, B. (2016). Pelaksanaan Supervisi Klinis Dalam Meningkatkan Mutu Kinerja Guru Di Sekolah Dasar. Jurnal Pendidikan - Teori, Penelitian, Dan Pengembangan, 1(11), 2194-2199. https://doi.org/https://doi.org/10.17977/jp.v1i12.8285.

Mishra, D. L., Gupta, D. T., \& Shree, D. A. (2020). Online Teaching-Learning in Higher Education during Lockdown Period of COVID-19 Pandemic. International Journal of Educational Research Open, 100012. https://doi.org/10.1016/j.ijedro.2020.100012.

Muhammad, N. (2019). Peningkatan Kinerja Guru Melalui Supervisi Edukatif Kolaboratif Secara Periodik Di SDN Lamongrejo 4 Ngimbang Lamongan. Jurnal Pendidikan Islam, 4(1), 2-8. https://doi.org/10.37286/ojs.v4i1.33.

Nasution, T. (2017). Konsep Dasar Pendidikan Kewarganegaraan Dalam Membangun Karakter Siswa. Jurnal Ilmu Sosial \& Budaya, 1(2), 1689-1699. http://jurnal.uinsu.ac.id/index.php/ijtimaiyah/article/download/1393/1130.

Oyedotun, T. D. (2020). Sudden change of pedagogy in education driven by COVID-19: Perspectives and evaluation from a developing country. Research in Globalization, 2(June), 100029. https://doi.org/10.1016/j.resglo.2020.100029.

Patricia, A. (2020). College Students' Use and Acceptance of Emergency Online Learning Due to COVID-19. International Journal of Educational Research Open, 100011. https://doi.org/10.1016/j.ijedro.2020.100011.

Rahmawati, M., \& Latifah, M. (2020). Penggunaan Gawai, Interaksi Ibu-Anak, Dan Perkembangan Sosial-Emosional Anak Prasekolah. Jur. Ilm. Kel. \& Kons., 13(1), 7586. https://doi.org/10.24156/jikk.2020.13.1.75 PENGGUNAAN.

Rawin, \& Brantasari, M. (2018). Pembentukkan Karakter Peserta Didik Melalui Pemanfaatan Lagu Anak-Anak Di Kelompok Bermain Flamboyan Desa Kota Bangun Iii Kecamatan Kota Bangun Kabupaten Kutai Kartanegara Pada Tahun Ajaran 2016/2017. Jurnal Warna : Pendidikan Dan Pembelajaran Anak Usia Dini, 3(1), 5061. https://doi.org/10.24903/jw.v3i1.208.

Sahu, P. (2020). Closure of Universities Due to Coronavirus Disease 2019 (COVID-19): Impact on Education and Mental Health of Students and Academic Staff. Cureus, 2019(4), 4-9. https://doi.org/10.7759/cureus.7541.

Samaha, M., \& Hawi, N. S. (2016). Computers in Human Behavior Relationships among smartphone addiction, stress, academic performance, and satisfaction with life. Computers in Human Behavior, 57, 321-325. https://doi.org/10.1016/j.chb.2015.12.045. 
Sudarmiani, S. (2013). Membangun Karakter Anak Dengan Budaya Kearifan Lokal Dalam Proses Pembelajaran Di Sekolah. EQUILIBRIUM: Jurnal Ilmiah Ekonomi Dan Pembelajarannya, 1(1), 54-72. https://doi.org/10.25273/equilibrium.v1i1.556.

Sugiyono. (2017). Metode Penelitian Kualitatif. Bandung: Alfabeta.

Suheli. (2018). Manajemen Peserta Didik Berbasis Pesantren dalam Pembentukan Karakter. Jurnal Kependidikan, 6(2), 207-221. https://doi.org/10.24090/jk.v6i2.2258.

Suradi, A. (2018). Kinerja Guru Pendidikan Agama Islam Di Sekolah Academic Supervision of Headmaster on Teacher Performance of Islamic Religious in Elementary School 79 Bengkulu City. Jurnal Pendidikan Dasar Islam, 5(1), 13-29. https://doi.org/10.24252/auladuna.v5i1a2.2018.

Suryaman, S., \& Karyono, H. (2018). Revitalisasi Pendidikan Karakter Sejak Usia Dini di Kelas Rendah Sekolah Dasar. Sekolah Dasar: Kajian Teori Dan Praktik Pendidikan, 27(1), 10-18. https://doi.org/10.17977/um009v27i12018p010.

Sutiyono. (2013). Penerapan Pendidikan Budi Pekerti Sebagai Pembentukan Karakter Siswa Di Sekolah: Sebuah Fenomena Dan Realitas. Jurnal Pendidikan Karakter, O(3), 309320. https://doi.org/10.21831/jpk.v0i3.2753.

Utomo, C. B., \& Muntholib, A. (2018). Implementasi Pendidikan Karakter dalam Membentuk Sikap dan Perilaku Sosial Peserta Didik Melalui Pembelajaran Sejarah di SMA PGRI 1 Pati Tahun Pelajaran 2017/2018. Indonesian Journal of History Education, 6(1), 1-13. https://journal.unnes.ac.id/sju/index.php/ijhe/article/view/27332.

Wahyuningsih, S. (2017). Lagu Anak sebagai Media dalam Mendidik Karakter Anak Usia Dini. ThufuLA: Jurnal Inovasi Pendidikan Guru Raudhatul Athfal, 5(1), 150. https://doi.org/10.21043/thufula.v5i1.2356.

Wong, G. L. H., Wong, V. W. S., Thompson, A., Jia, J., Hou, J., Lesmana, C. R. A., Susilo, A., Tanaka, Y., Chan, W. K., Gane, E., Ong-Go, A. K., Lim, S. G., Ahn, S. H., Yu, M. L., Piratvisuth, T., \& Chan, H. L. Y. (2020). Management of patients with liver derangement during the COVID-19 pandemic: an Asia-Pacific position statement. The Lancet Gastroenterology and Hepatology, 5(8), 776-787. https://doi.org/10.1016/S2468-1253(20)30190-4. 